\title{
Chinese National Health Commission's Reporting Strategies on COVID-19
}

\author{
Mateja PETROVČIČ́*
}

\begin{abstract}
The coronavirus pandemic has changed our lives dramatically and caused much fear around the world. While social media can contribute to faster information flow, this environment also gives rise to intensifying anxiety. This paper examines the research questions of how the Chinese National Commission (NHC), as the main authority for the health-related issues, presents the news about COVID-19 pandemic to English-speaking readers, which topics related to the coronavirus are stressed most, and what reporting strategies are used in presenting the current events and issues. The results indicate that the authorities are well-informed about the dynamics of public attention, since the same dynamics can be observed in the amount and structure of news. Moreover, from the perspective of reporting strategies we can see that the authorities subtly follow all the criteria that were proposed to allay fears and slow down or break the spiral of negativism with regard to the pandemic.
\end{abstract}

Keywords: COVID-19, fear, media, National Health Commission, reporting strategies

\section{Strategije poročanja Nacionalne zdravstvene komisije o koronavirusu}

\section{Izvleček}

Pandemija koronavirusa je močno spremenila naše življenje in povzročila različne strahove. Socialna omrežja sicer prispevajo $\mathrm{k}$ hitrejšemu pretoku informacij, vendar pa so tudi vir za intenziviranje strahu. Pričujoči članek obravnava raziskovalna vprašanja, kako Nacionalna zdravstvena komisija Ljudske republike Kitajske kot osrednji organ za zdravstvena vprašanja angleško govorečim bralcem predstavlja novice o pandemiji novega koronavirusa, katere teme, povezane s tem, so najbolj poudarjene, in katere strategije poročanja zasledimo pri predstavitvi trenutnih dogodkov in aktualnih zadev. Rezultati raziskave kažejo, da so oblasti videti dobro obveščene o tem, čemu javnost posveča največ pozornosti, saj enako dinamiko poročanja opazimo tudi pri količini in strukturi uradnih novic. Poleg tega $z$ vidika strategij poročanja vidimo, da oblasti mehko sledijo vsem predlaganim kriterijem, kako ublažiti strahove in upočasniti ali celo prekiniti spiralen razvoj negativizma.

Ključne besede: COVID-19, strah, mediji, Nacionalna zdravstvena komisija, strategije poročanja

Mateja PETROVČIČ, Assoc. Professor, Department of Asian Studies,

University of Ljubljana.

Emal address: mateja.petrovcic@ff.uni-lj.si

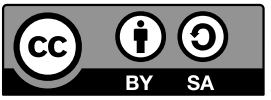




\section{Introduction}

The COVID-19 pandemic poses a huge challenge to society. While political actions are taken in the realm of health management, public security, and financial economics, psychological health is probably the most neglected aspect of the pandemic (Schimmenti, Billieux, and Starcevic 2020,41). Societal safety measures are necessary to reduce the spread of COVID-19, but they can make us feel isolated and lonely, and increase stress and anxiety (CDC 2020). Among other effects, stress can cause feelings of fear, frustration, helplessness, and other similar emotions.

Numerous studies have already shown that fear is a basic and adaptive emotion that is activated in response to a perceived threat. It serves to mobilize energy to deal with potential danger (Schimmenti, Billieux, and Starcevic 2020; Mertens et al. 2020, among others). From this perspective, fear can be a positive force, and a rational response is to understand and manage the threat of harm. However, an irrational but common response may lead to negative effects and result in panic ( $\mathrm{Ng}$ and Kemp 2020, 752).

In search of news about the novel coronavirus, people often browse Internet or use online social media platforms as the main source of information. According to the 47th Statistical Report on Internet Development in China, as of December 2020, online news sites had 743 million users, or $75.1 \%$ of China's total netizen population (China Internet Network Information Center 2021). We are all consciously or unconsciously influenced by these new communication channels. Ng and Kemp $(2020,752)$ thus pointed out that the established press and media need to understand that they have a responsibility not to inflame fears just to promote their stories or attract more readers and viewers. This is of great importance because social media can be a fear-generating environment, and serve as a tool both for searching and producing information, which easily results in fake news. Therefore, one should especially pay attention to evaluating of the reliability of the information received in such context. In general, it is not surprising at all that since the outbreak of the pandemic we have been exposed to a negative discourse that heightens concerns and promotes irrational fears on a daily basis.

This article examines the research questions of how Chinese authorities present the news about the COVID-19 pandemic to English-speaking readers, which topics related to the coronavirus are stressed most, which reporting strategies are used to deliver information, and towards which direction the informing policy goes. 
The rest of this paper is organized as follows. In the section National Health Commission, we introduce the National Health Commission as the main authority on the field of health policies in China, which is consequently expected to provide relevant news and information about the novel coronavirus. At this stage, a general overview of the dynamic of news is outlined, whereas a more detailed analysis of the findings is presented in later sections. To place the news within a broader context, Section Reporting Strategies first presents the reporting strategies in journalism and outlines the framework proposed by Gyldensted (2015), followed by a brief review of other studies that are relevant for this discussion. In Section Studies of Public Attention, the focus is placed on studies of public attention and fear. Their results are then in Section Nerws on the NHC's Website interwoven with the findings of our study that demonstrates how the NHC's news subtly follows the various guidelines of how to act in the current pandemic. Finally, Section Conclusions summarizes the results and draws the conclusions of this study.

\section{National Health Commission}

The National Health Commission of the People's Republic of China (NHC) is a central government commission sitting under the State Council, which is responsible for formulating health policies in the country. Among other functions, the NHC plays an important role in coordinating the national efforts to combat the COVID-19 pandemic (National Health Commission of the PRC 2020). As the leading agency in China on this field, it is expected to provide news and information about current health issues.

The NHC's website does indeed its contents update daily, and in the first three quarters of 2020 the News section included more than 2,300 pieces of news in English. The distribution of posts mainly corresponds to the findings of Li Sijia et al. (2020,3), who observed a peak of searches on Weibo in late January and February, then a drop, followed by another rise in March, and a gradual decline afterwards. Our findings have shown a slight time delay in the intensity of news, as these peaks were observed from February to April 2020.

Li Sijia et al. $(2020,3)$ explained that the trend on Chinese social media largely reflects the progress of the pandemic in China. The outbreak of COVID-19 and the spread from Wuhan to the rest of the country corresponds to the first peak. The subsequent drop reflects the apparent promise with regard to containing the virus, followed by a minor relapse in March. Cui and Kertész $(2021,9)$ further observed an increase in social media activities on April 4 due to the national Qingming Festival, or Tomb-Sweeping Day, where those who died in the COVID-19 
pandemic were mourned. In the months afterwards there was a decline in the number of few posts. The dynamics of news releases by the NHC are quite similar to those reported in previous studies, as shown in Figure 1.

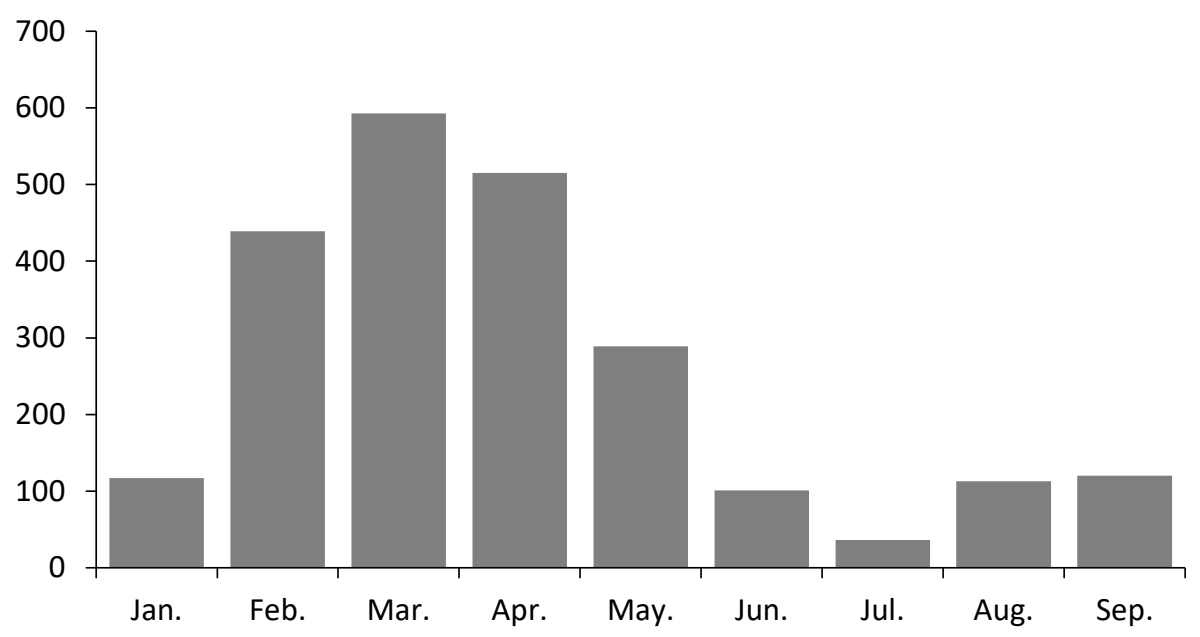

Figure 1. Amount of news stories by month (1.1.2020-30.9.2020).

Although the intensity of publishing news slowly decreased, the writing style and reporting strategies remained unchanged. As will be further demonstrated later, the news stories posted by the NHC tend to reflect a positive orientation, even though the main topics are the coronavirus and pandemic-related issues.

\section{Reporting Strategies}

By definition, journalism refers to collecting, compiling, and delivering fact-based news and other related information to the general public in an unbiased manner (MasterClass 2021). Gyldensted (2015) questions the inclusion of word "unbiased" here, although a critical part of journalists' self-image is that a journalist covers reality as it is without differentiating whether a story will prove to be positive or negative. Gyldensted (2015), however, argues that this is not the way it unfolds in reality. Moreover, news reporting has a negative bias. The author adds that sometimes unbalanced and negative bias stems from journalism's own methodology, even if this was not intended. Journalists seek to challenge authorities, fight for the weak against the powerful. They are on the side of the little guy. Therefore, 
classic journalism would normally zoom in on a person's victim status and any negative spiral associated with this (ibid.).

Moreover, Gyldensted (2015) claims that today we face a problem with being too obsessed with reporting negative issues, stemming from a belief that only by focusing on what is wrong with the world, and as such being "critical", can we keep power accountable (Gyldensted 2015,6). And from the perspective of the audience, a study from 2011 showed that people are tired of negative critical journalism (Rosenstiel and Mitchell 2011). Many respondents reported that the news gives them a feeling of hopelessness, which is related to the generally accepted negative format (Gyldensted 2015, 6).

Therefore, Gyldensted proposed changes to journalism based on behavioural sciences like positive psychology, moral psychology and neuroscience, to create content that involves and inspires readers. According to her, constructive journalism is necessary for turning the wheels of society forwards, counterbalancing the negativism that may push us backwards (ibid.). A more constructive approach to reporting encompasses all classic domains, from domestic affairs, foreign news, politics, and health, to science and business. The same applies to genres, from breaking news, top stories, features, interviews, investigative journalism to debates (ibid., 46).

Seligman (2012) points to five elements of well-being: positive emotions, engagement, relationships, meaning, and accomplishment. Positive emotions include happiness and satisfaction, but also more nuanced feelings like gratitude, trust, hope and respect. Engagement is the mental state of operations in which a person performing an activity is fully immersed in feelings of energized focus, full involvement and enjoyment. Relationships exist in relation to family and friends as well as in a professional context, and they can focus on positive, constructive and close relationships. Meaning is related to attaching oneself to something larger than oneself. And finally, Accomplishment means to reach a personal goal. The five key concepts can be expressed with the acronym "PERMA".

The PERMA model can also be applied to constructive journalism, and according to Gyldensted (2015) it is possible to transform these principles to the corresponding reporting guidelines. For example, questions that focus on positive emotions, include Who is hopeful? Who is grateful? Who is experiencing flow? Who has put in a significant effort? Who is passionate about something? Potential questions that focus on relationships in news reports would be Who helped? Who has been brought together? Questions that highlight meaning would be, for example, Who is wiser now? What did they learn? What is the inspiration for the others? What is the meaning? What is the higher purpose? What will be the higher meaning? And finally, 
accomplishments are addressed with the questions What did it take? What was overcome? What was achieved? What will be achieved? (cf. Gyldensted 2015, 72-73). As will be seen more clearly below, all of these items are included in the news on the NHC's website that are written by China Daily.

In short, Gyldensted concludes that people are most longing for meaningful content through inspiring, authentic storytelling. Behavioural research also suggests that in the presence of positive emotions we become more creative, collaborate better and are able to see the big picture (ibid., 52). Moreover, Schimmenti, Billieux, and Starcevic (2020) also argue that improving the psychological health of individuals is vital for strengthening the resilience of society as a whole.

Numerous previous studies have shown that, in general, some societies in East Asia and the Pacific had better performance in containing the spread of COVID-19, compared to the rest of the world. Ma, Wang and Wu $(2021,59)$ explored how East Asian regions have dealt with the pandemic, and how both the infection and government policy have affected emotional well-being. Their analysis shows that East Asia's success, compared with the selected Western societies, can be attributed to stronger and more prompt government responses, as well as better civic cooperation. The importance of cooperation between the state and civil society in the search for an effective pandemic response was also argued in Schwartz (2014, 1139). The frequently cited South Korean philosopher Byung-Chul Han sees the main reason for successful coping with pandemic in an authoritarian mentality which comes from the cultural tradition of Confucianism. Therefore, the citizens in East Asia are said to be more likely to obey the orders of the government in a health emergency. In addition, Confucian culture also contributed to the selective confinement of the virus, as since people trust intellectuals and experts the orders are respected, and the individual comes after the community (Noh 2020). Moreover, Rošker $(2021,325)$ draws attention to the fact that safety measures were the most successful in the East Asian societies with democratic, and not autocratic political systems, therefore an authoritarian mentality is not the primary reason for the effectiveness. Instead, the crucial factors are indeed related to Confucianism, and specifically to the system of interpersonal relations. Moreover, as stated in Schimmenti, Billieux and Starcevic $(2020,41)$, the resilience of a society facing such challenging events also depends on how its individual members cope with their anxieties and fears. On the psychological level, a positive approach is more viral than a negative one, which indirectly contributes and leads to more effective measures being taken.

Let us return back to the debate about reporting strategies. It was shown that a positive approach is beneficial for various reasons. The question then arises: why 
are there so many negative stories in the media if readers are reluctant to engage in negativism?

The overall purpose of news stories is to provide information about events, to stimulate thinking and shape readers' viewpoints. To achieve this, news stories have to elicit readers' attention first, which is known as the pragmatic function. Headlines are of great importance because they influence whether someone will want to read the full text. In other words, they should grab readers' attention so that people are drawn to the article. Therefore, a short, punchy writing style is used that both captures readers' interest and satisfies space constraints (Hagin 2018). Moreover, marketing experts know how to grab attention using fear and sensational news. This brings us back to promoting negative emotions rather than their positive counterparts.

While the use of sensational language can trigger further reading, as Maria Konnikova notes a headline changes the way people read an article and remember it. The headline frames the rest of the experience and sets the tone for what follows. Psychologists have long known that first impressions really do matter. What we see, hear, feel, or experience in our first encounter with something colours how we process the rest of it (Konnikova in Hagin 2018). The reporting style therefore has a certain effect and influence on people's perceptions.

Although there are various views in the literature on whether news journalism mirrors society or whether it creates and moves it, extensive negative reports and stories in both the traditional and social media have served to generate fear, panic, stigmatization, and instances of xenophobia. In the case of the COVID-19, news reporting can even more intensely increase fears because the threat is novel, unseen, and potentially fatal, especially to those most vulnerable groups in society: the sick and aged ( $\mathrm{Ng}$ and Kemp 2020, 752). Therefore, the authors argue that, among others reasons, avoiding inflammatory language that generates fear and panic is essential to break the circle of fear and panic. To achieve this, it is desirable to understand where the emphasis of public attention is placed.

\section{Studies of Public Attention}

Based on the above, it is not surprising that the COVID-19 pandemic has already given to several studies that analyse data from various social media. Scholars have recognized that using social media data may provide timely understanding of current issues (Li Sijia et al. 2020), and that microblogging services provide 
important insights into the functioning of a society. That user-generated content on social media provides an important source for understanding public emotions and concerns was already argued in Li Xiaoya et al.(2020). The authors stated that a close look at how the public were affected during the COVID-19 pandemic could help us understand people's reactions and thoughts in the face of the new crisis. Thus, it is crucial for policymakers to understand people's opinions toward the pandemic so that they can balance the concerns of stopping the pandemic on the one hand, and keeping people in good spirits on the other hand, as well as anticipate people's reactions to certain events and policies so that the policymakers can prepare in advance. Cui and Kertész (2021) also claimed that in this age of information deluge the dynamics of public attention is of great importance in many areas, including education, politics, marketing and governance. They stated that identifying the patterns of online attention dynamics and their relationships to specific events and measures during pandemic may contribute to more efficient and effective decisions being made.

Cui and Kertész (2021) conducted a survey on hashtags on Sina Weibo, and grouped the users' points of interest into various categories. They claimed that specific events, measures and developments during the epidemic affected the emergence of different kinds of hashtags. Their study also noticed algorithmic interference from Weibo, and the authors were able to pinpoint direct interventions from the side of the provider with regard to the ranking of hashtags (Cui and Kertész 2021, 15). They suppose that as one of the most popular and influential social media providers in China, Weibo might have taken on the responsibility during the global public health emergency to keep people informed about related news in China and around the globe, by means of changing the algorithm towards COVID-related hashtags to promote crucial news (ibid., 12). As we shall see a bit later, news on the NHC's website is similar in distribution and thematic coverage as was found in this earlier study.

Li Xiaoya et al. (2020) focused on people's emotions and the emotional triggers on Weibo. Their findings revealed that the trend of worry-which is the closest emotion to fear among the six analysed emotions-is largely in line with the trend of the general intensity of the COVID-related posts (Li Xiaoya et al. 2020, 4). Speaking of fear, initial reports indicate that people's fears of the coronavirus related to different topics. Schimmenti, Billieux, and Starcevic (2020) pointed out that fear during the COVID-19 pandemic is organized on the psychological level around four interrelated dialectical domains. The first domain relates to a sense of physical vulnerability and potential infections; the second domain relates to interpersonal relationships, which are considered the core of human identity; the third domain concerns the cognitive aspect of mastering certain situations; and the last 
domain concerns the behavioural consequences of taking or not taking actions. All these fear domains and their related aspects formed the complex experience of fear during the pandemic.

Similarly, Mertens et al. (2020) showed that more exposure to threatening information (e.g., reading news bulletins about new deaths, social media posts) would increase fear of the virus. Under such circumstances, which may apply to the current COVID-19 crisis, it may not be very helpful to maximize fear, as this could only increase distress (ibid., 6). The authors stress that fear appeals in the media should be used carefully, although further studies with empirical evaluation would be needed to find out whether fear appeals are working for the current situation or not.

Mertens et al. (2020) further suggested that if there is the causal connection among these constructs then there are opportunities for policymakers and journalists to reduce excessive fear. One way to do this is to ensure that communication is clear and unambiguous, because uncertainty tends to increase fear. Information should also be provided without sensationalism or disturbing images, although the analysis of the news on the NHC's website shows that some of the posts did have such content.

\section{News on the NHC's Website}

In this study we analysed all news stories posted from January 1, 2020, to September 30, 2020. As already noted in Section National Health Commission, the dynamics and distribution of posts is in line with the findings of Li Sijia et al. $(2020,3)$, although with a slightly time delay. While the peak of hashtags on Weibo was in late January and February 2020, followed by another one in March, we observed the most active months to be February, March, and April. Afterwards, there was a notable decrease in intensity. According to the interpretation of Cui and Kertész (2021,3), collective attention towards online news decays with time due to the fading novelty and attractiveness in competition with other news stories.

We also mentioned in Section National Health Commission that the writing style and reporting strategies remained unchanged in the period examined. But before we focus on the contents of the posts, we must look at the origin of news on the NHC's website. 
Table 1 below shows that the NHC's stories originate from various sources, with Xinhua News Agency and China Daily as the top two providers.

Table 1: Sources of news published on the NHC's website (1.1.2020-30.9.2020)

\begin{tabular}{|l|l|}
\hline Source of news & No. of items \\
\hline Xinhua & 1,129 \\
\hline China Daily, China Daily Global, chinadaily.com.cn & 1,046 \\
\hline Ministry of foreign affairs (fmprc.gov.cn) & 56 \\
\hline National Health Commission (en.nhc.gov.cn) & 40 \\
\hline The State Council of the People's Republic of China (english.www.gov.cn) & 24 \\
\hline China Global Television Network (CGTN) & 4 \\
\hline $\begin{array}{l}\text { The Knowledge Center for China's Experiences in Response to COVID-19 } \\
\text { (covid19.alliancebrh.com) }\end{array}$ & 2 \\
\hline People's Daily Online (en.people.cn) & 1 \\
\hline Qiushi (http://en.qstheory.cn/) & 1 \\
\hline N/A & 20 \\
\hline Total & $\mathbf{2 , 3 2 3}$ \\
\hline
\end{tabular}

Almost half of the news stories are provided by China Daily and its variants. The other half derive from Xinhua News Agency. The diversity of sources is in fact only superficial, since Xinhua News Agency is the official state-run press agency of the People's Republic of China, whereas China Daily is a quasi-official newspaper of the Chinese government that reports on their own reading of public internet postings by individuals on the BBS (bulletin board system), i.e., the microblogs (weibo), and blogs (boke). In other words, this is government controlled "unofficial press" news disseminated on the Internet (Lanigan 2015, 491).

The China Daily on its website states that being "an authoritative national English-language media organization bridging China and the rest of the world, it is committed to telling China's stories well and making China's voice heard". Also, "in an era when the world is experiencing a once-in-a-century change, China, as a rising country, needs to tell the world diverse, real and multidimensional stories about the country through various media". This also includes the otherwise "politicized reporting on the fight against COVID-19 that needs to get the facts straight so that the readers and viewers have a more balanced view" (Song 2021). Lanigan (2015), on the other hand, understands that news items and stories posted on China Daily have a singular editorial purpose - a propaganda effort by the 
central government, in the guise of news reporting, about government policy on social issues of the day (ibid., 506).

Either way, being a newspaper belonging to the Chinese government, it reflects the official orientation towards reporting the news. The analysis of contents has shown strong overlapping with the results of Cui and Kertész (2021, 8), who grouped the Weibo hashtags into the following categories: Bad News, Good News, Regulations, Life Influence, Front Lines, and Science.

The Bad Nerws category comprised news on confirmed infections and victims of the novel coronavirus. On the NHC's website, there are daily briefings on novel coronavirus cases in China, posted by the NHC itself (source: en.nhc.gov.cn). These reports are written in a factual writing style with information based on facts and "real" data. In general, such news stories do not carry any emotional load, and try to keep the neutral reporting position. However, a closer look reveals several traces of positive orientation. Where possible, paragraphs end with a sentence reporting that "serious cases decreased by [number]", which creates an uplifting tone. Similarly, news headlines tend to offer a positive perspective even though the topic itself is new infections, e.g. Proportion of severe COVID-19 cases drops significantly: official (17.2.2020), Novel Heroes: Wuban hospital head says new fever cases on decline (21.2.2020), China sees overall decline in numbers of new confirmed COVID-19 cases (21.2.2020), Capital sees no new cases in 24-hours (23.2.2020), New virus cases in Wuban expected to drop to zero by late March (6.3.2020), New Xinjiang cases drop to single digits (13.8.2020), Chinese mainland reports no new locally-transmitted COVID-19 cases (2.9.2020). Several news stories also stress the foreign origin of new infections, e.g. China's Henan reports 38 imported asymptomatic cases (14.9.2020), Shanghai reports 5 new imported COVID-19 cases (29.9.2020). According to Gyldensted (2015), the explanatory style is a positive or negative psychological attribute that indicates how people explain to themselves why they experience a particular event. A negative explanatory style typically attributes negative outcomes to internal, stable, and global causes, whereas a positive explanatory style typically attributes negative outcomes to external, temporary, or specific causes. Most often the positive explanatory style builds an upward mental spiral (ibid., 19-20).

Therefore, the "bad news" actually moves towards the "good news", which in Cui and Kertész's (2021) study focus on cases of recovery, sufficiency of supplies, and decreases in daily infections or deaths. Examples of the NHC's headlines that reflect this include 22 workers released in good health after two-week quarantine (1.2.2020), Cabin hospitals see good treatment results, says health official (15.2.2020), Good news on research front in contagion battle (18.2.2020), Nation steps up supply of 
medical goods (9.4.2020), and Treatment for expectant mothers with COVID-19 sees good effect: official (22.4.2020).

The news stories that fit into the Cui and Kertész's (2021) Regulations category consist of announcements by authorities of national, regional, institutional laws, rules and regulations associated with public behaviours and concerns during the pandemic. The source of such news was often Xinhua News Agency, with such articles found to a greater extent in the Chinese version of the NHC's website, rather than the English one.

On the other hand, the posts that originate from China Daily are mainly news stories in the Live Influence or Front Lines categories. These stories typically evoke positive emotions, stressing the tenacity, courage and sacrifice of frontline workers and common citizens. Some of the headlines include Volunteer drivers show bravery on front line (6.02.2020), Doctor on the front line believes epidemic battle will be won (20.02.2020), On the front line, it's one for all, all for one (24.02.2020), Novel heroes: Wuhan post-90s policemen work at front line to fight epidemic (24.02.2020), Critical care doctor spends birthday on front lines in Wuban (3.03.2020), Without blinking, Beijing nurses stepped into action (12.05.2020), and so on. These news stories stress the idea that the coronavirus is an enemy that should be fought and can be defeated, as also observed in Kalinin (2021). These stories also indirectly address various domains of fear, as elaborated in Schimmenti, Billieux, and Starcevic (2020) and outlined in Section Studies of Public Attention. They relate to interpersonal relationships, the cognitive aspect of mastering situations, and the question of taking or not taking actions. As for writing strategies, these stories are emotionally moving, authentic and engaging. We can observe a strong emphasis on all five elements of well-being and constructive journalism: positive emotions, engagement, relationships, motivation, and accomplishment.

Similar to Cui and Kertész's (2021) findings, news on the NHC's website also pay stories particular attention to the role of science. This category incorporates scientific understanding of the virus and its properties, vaccine development, and methods of public protection offered by authoritative doctors. The NHC's news regularly presents stories from this field, such as Chinese scientists working with int'l peers on virus vaccine, cure (15.2.2020), Scientists target major cause of critically ill virus deaths (16.2.2020), Plasma transfusion therapy shows success in treating virus (26.2.2020), Chinese scientists make progress in developing coronavirus vaccine, antibody drugs (2.4.2020), and Dying coronavirus patients saved by lung transplants (13.5.2020). 
Among the NHC's news stories, we have also detected a remarkable number of articles that stress the role of Traditional Chinese Medicine (TCM), with more than one hundred posts discussing the value and efficiency of TCM regarding the novel coronavirus. The titles of these stories are clear and straightforward, and include TCM plays important role in COVID-19 treatment (15.4.2020), TCM use reduces COVID-19 death risk: expert (18.4.2020), Chinese expert team holds discussions with Malaysian practitioners on TCM against COVID-19 (23.4.2020), TCM effective in treating COVID-19 patients in Wuban: expert (24.4.2020), TCM effective in preventing, treating emerging infectious diseases: Official (27.4.2020), Understanding TCM and its role in fighting COVID-19 (9.5.2020), TCM provided COVID-19 patients with hope, advisor says (22.5.2020), Bigger role for TCM urged in disease control (28.5.2020), TCM leaves its mark in COVID-19 recovery (29.5.2020), TCM belps fight COVID-19 in Xinjiang (10.8.2020), and 'People's Hero' shows Chinese virtues in TCM work (16.9.2020). It is clear that these stories aim to increase the reputation and influence of TCM abroad, as they appear only in the English version of the NHC's website, whereas the stories in Chinese hardly contain any mentions of TCM.

\section{Conclusions}

The COVID-19 pandemic has changed our lives dramatically and created several challenges. Various measures have been taken to cope with the spread of the virus, which are undoubtedly necessary, but the long-term nature of the pandemic has nevertheless increased stress and anxiety. Several previous studies have shown that people face different kinds of fears that are traceable to the user-created posts on social media platforms. It has been argued that nowadays social media plays an increasingly significant role in communicating information and news, which may unfortunately lead to even more stress and fear due to the flood of bad news, including false news. According to $\mathrm{Ng}$ and $\mathrm{Kemp}(2020,753)$, fear arises through a circle. Social networks may produce fear-stimulating contents, which are strengthened by confusing messages from health officials. These are further enhanced by striking media headlines and scare stories that produce even more contradictory messages, and the result is a spiral of increasing fear and panic. Therefore, to slow down the negative spiral, or finally move it towards a positive direction, scholars have proposed several additional measures, from detecting and eliminating misinformation, to delivering only clear, consistent, and well-considered guidance from the authorities, as well as avoiding inflammatory language that generates fear and panic. 
Our study has shown that news stories posted on the NHC's website systematically and subtly follow all these criteria. The contents are delivered in a positive way that creates uplifting emotions, and stresses interpersonal solidarity, which is one of the most effective tools in safety measures. This is also closely related to a certain degree of self-discipline, motivation, and placing the community above the individual.

We have shown that the posts of the NHC coincide with the collective attention towards the pandemic, which suggests that the authorities are well-informed about the dynamics of people's queries on social media, especially Weibo. Cui and Kertész (2021) support the idea that targeted and timely stimuli should be given to hold the attention and raise the awareness of the public throughout the pandemic to prevent future waves of COVID-19. From another point of view, interference in citizens' Internet activities can be considered inadmissible, and a feature of an authoritarian regime.

This overlap can also be partly attributed to the fact that the NHC publishes news written by China Daily, which is a quasi-official newspaper of the Chinese government, with a focus on public Internet postings by individuals. Besides, as noted in Gyldensted (2015), people long for meaningful content through inspiring, authentic storytelling, and thus personal stories seem trustworthy and easy to identify with. Such stories also tend to be "liked" and "shared" on social media. This is also the orientation of China Daily, which is shifting to positive value rhetoric as observed in Lanigan $(2015,519)$. The strategy to create emotionally moving, authentic and engaging contents is in line with the concept of constructive journalism, which may contribute to turning the wheels of society forwards, counterbalancing the negativism that may push us backwards.

The positive image that the NHC creates through daily news, outwardly shows that everything is under control in China. This positive approach could soothe the world's reactions and fears regarding the coronavirus. From a common foreign reader's perspective, this approach diverges from one's expectations. Namely, classical journalism would normally zoom in on a person's victim status and promote a negative spiral. Positive news stories are therefore not very common within the framework of traditional journalism.

Besides, to elicit readers' attention we are often exposed to news that emphasizes the pragmatic function and is made more appealing with various attractive devices, such as sensational headlines. However, during a pandemic negative emotive language may worsen people's psychological health and cause more fear. 
The general image that the NHC outwardly creates functions very reassuringly and counterbalances the news stories that provoke fear. The selected topics on the one hand reflect the points of interest of domestic users, and on the other hand promote stories about the effectiveness of the Chinese system and society.

\section{Acknowledgement}

The research for this paper was supported by the Slovenian Research Agency (ARRS) in the framework of the research core funding Asian Languages and Cultures (P6-0243).

\section{References}

CDC. 2020. "COVID-19 and Your Health." Centers for Disease Control and Prevention. February 11, 2020. Accessed June 20, 2021. https://www.cdc. gov/coronavirus/2019-ncov/daily-life-coping/managing-stress-anxiety. html.

China Internet Network Information Center. 2021. "The 47th Statistical Report on the Development of Internet in China From CNNIC (February 2021)." China Internet Network Information Center, February 2021. https://www.cnnic.com. cn/IDR/ReportDownloads/202104/P020210420557302172744.pdf.

Cui, Hao, and János Kertész. 2021. "Attention Dynamics on the Chinese Social Media Sina Weibo during the COVID-19 Pandemic." EPJ Data Science 10 (1): 1-16. https://doi.org/10.1140/epjds/s13688-021-00263-0.

Gyldensted, Cathrine. 2015. From Mirrors to Movers: Five Elements of Positive Psychology in Constructive Journalism. Lexington: GGroup Publishers.

Hagin, Darcy. 2018. "How Article Headlines Attract and Mislead Readers." PR Boutiques International (blog), October 25, 2018. https://prboutiques.com/ how-article-headlines-attract-and-mislead-readers/.

Kalinin, Oleg. 2021. "Comparative Analysis of Coronavirus Metaphoric Representation in Chinese and Russian Online Media." Acta Linguistica Asiatica 11 (2): 51-63.

Lanigan, Richard L.2015. "Netizen Communicology: China Daily and the Internet Construction of Group Culture.” Semiotica 2015 (207): 489-528. https:// doi.org/10.1515/sem-2015-0056. 
Li, Sijia, Yilin Wang, Jia Xue, Nan Zhao, and Tingshao Zhu. 2020. “The Impact of COVID-19 Epidemic Declaration on Psychological Consequences: A Study on Active Weibo Users." International Journal of Environmental Research and Public Health 17 (6): 2032. https://doi.org/10.3390/ijerph17062032.

Li, Xiaoya, Mingxin Zhou, Jiawei Wu, Arianna Yuan, Fei Wu, and Jiwei Li. 2020. "Analyzing COVID-19 on Online Social Media:Trends, Sentiments and Emotions." ArXiv: 2005.14464 [Cs], June 2020. http://arxiv.org/abs/2005.14464.

Ma, Mingming, Shun Wang, and Fengyu Wu. 2021. "COVID-19 Prevalence and Well-Being: Lessons from East Asia.” In World Happiness Report 2021, 5790. https://happiness-report.s3.amazonaws.com/2021/WHR+21_Ch3.pdf.

MasterClass. 2021. "9 Types of Journalism: Soft News vs. Hard News Explained - 2021.” MasterClass, May 13, 2021. https://www.masterclass.com/articles/ types-of-journalism.

Mertens, Gaëtan, Lotte Gerritsen, Stefanie Duijndam, Elske Salemink, and Iris M. Engelhard. 2020. "Fear of the Coronavirus (COVID-19): Predictors in an Online Study Conducted in March 2020." Journal of Anxiety Disorders 74 (August): 102258. https://doi.org/10.1016/j.janxdis.2020.102258.

National Health Commission of the PRC. 2020. http://en.nhc.gov.cn/search. html?search Text=2020.

Ng, Kwan Hoong, and Ray Kemp. 2020. "Understanding and Reducing the Fear of COVID-19." Journal of Zhejiang University. Science. B 21 (9): 752-54. https://doi.org/10.1631/jzus.B2000228.

Noh, Minjung. 2020. "Understanding South Korea's Religious Landscape, $\mathrm{Pa}$ tient 31, and COVID-19 Exceptionalism." In Teaching About Asia in a Time of Pandemic (Asia Shorts), edited by David L Kenley, 31-40. Ann Arbor, MI: Association for Asian Studies.

Rosenstiel, Tom, and Amy Mitchell. 2011. "The State of the News Media 2011. An Annual Report on American Journalism." Pew Research Center'sproject for Excellence in Journalism. https:/www.pewresearch.org/wp-content/uploads/ sites/8/2017/05/State-of-the-News-Media-Report-2011-FINAL.pdf.

Rošker, Jana S. 2021. "Kitajska filozofija življenja, relacijska etika in pandemija COVID-19.” Asian Studies 9 (3): 322-40. https://doi.org/DOI: 10.4312/ as.2021.9.3.323-340.

Schimmenti, Adriano, Joël Billieux, and Vladan Starcevic. 2020. “The Four Horsemen of Fear: An Integrated Model of Understanding Fear Experiences during the COVID-19 Pandemic." Clinical Neuropsychiatry: Journal of Treatment Evaluation 17 (2): 41-45.

Schwartz, Jonathan. 2014. "Achieving Effective Pandemic Response in Taiwan through State-Civil Society Cooperation: The Role of the Li Zhang." Asian Survey 54 (6): 1136-57. https://doi.org/10.1525/as.2014.54.6.1136. 
Seligman, Martin E. P. 2012. Flourish (A Visionary New Understanding of Happiness and Well-Being). New York: Atria Books.

Song, Chen. 2021. "40th Birthday, New Beginning." China Daily, May 27, 2021. https://www.chinadaily.com.cn/a/202105/27/WS60af71e4a31024ad0bac1e8a.html. 